https://doi.org/10.32689/2617-22242020-5(25)-15-30

Аракелова Інна Олександрівна, кандидат економічних наук, доцент, докторант Донецького державного університету управління, м. Маріуполь, 87513, м. Маріуполь, вул. Карпінського, 58, е-таіl: iarakelova@gmail.com, тел.: +38050608 76 04, https://orcid.org/0000-0001-9582$793 X$

Аракелова Инна Александровна, кандидат экономических наук, дочент, докторант Донеикого государственно$2 о$ университета управления, г. Мариуполь, 87513, ул. Карпинского, 58, е-таil: iarakelova@gmail.com, тел.: +38050608 76 04, https://orcid.org/0000-0001-9582-793X

Arakelova Inna Oleksandrivna, Candidate of Economic Sciences, Docent, Doctoral candidate of Donetsk State University of Management, 87513, Mariupol, Str. Karpinskoho, 58, e-mail: iarakelova@gmail.com, tel.: +38050608 76 04, https://orcid.org/0000-0001-9582-793X

\title{
ДОСЛІДЖЕННЯ ВПЛИВУ ПРОЦЕСІВ ВИМУШЕНОÏ МІГРАЦIÏ НА ОКРЕМІ СОЦІАЛЬНО-ДЕМОГРАФІЧНІ ПОКАЗНИКИ БЕЗПЕКИ ТЕРИТОРІЙ НА ОСНОВІ НЕЙРОННИХ МЕРЕЖ
}

Анотація. Роботу присвячено актуальній проблемі дослідження впливу процесів міграції внутрішньо переміщених осіб на окремі соціально-демографічні показники безпеки регіонів. Особливого значення ця проблема набула після початку збройної агресії на території України у 2014 р., що призвело до стрімкого зростання процесів внутрішньої міграції. Зокрема, проаналізовано динаміку зміни наступних показників: демографічне навантаження, рівень безробіття, обсяг грошових переказів, близькість розташування до лінії розмежування.

У результаті проведеного дослідження автором було побудовано нейронну мережу типу карти Кохонена. Модель розподілила навчальну ви- 
бірку з регіонів країни на шість кластерів за рівнем чотирьох показників соціально-демографічної безпеки. Це дозволило оцінити вплив процесів вимушеної внутрішньої міграції на деякі аспекти соціально-економічної безпеки регіонів. На основі отриманої карти Кохонена показано, що Донецька та Луганська області, які безпосередньо межують із зоною ООС, мали катастрофічне зростання демографічного навантаження та рівня безробіття протягом досліджуваного періоду. Також у кілька разів скоротились обсяги грошових переказів мігрантів. Рівень соціально-економічної безпеки регіонів шостого кластеру за обраними показниками був визначений як небезпечний. Отримані результати можуть бути використані для формування регіональної соціально-економічної політики і відповідних національної демографічної та міграційної політик. Процес кластерного аналізу та запропонована система показників дозволяють здійснювати постійний моніторинг та оцінку впливу процесів вимушеної внутрішньої міграції на окремі аспекти соціально-економічної безпеки регіонів.

Ключові слова: соціально-демографічна безпека, демографічне навантаження, рівень безробіття, лінія розмежування, карта Кохонена, кластер.

\section{ИССЛЕДОВАНИЕ ВЛИЯНИЯ ПРОЦЕСОВ ВЫНУЖДЕННОЙ МИГРАЦИИ НА ОТДЕЛЬНЫЕ СОЦИАЛЬНО-ДЕМОГРАФИЧЕСКИЕ ПОКАЗАТЕЛИ БЕЗОПАСНОСТИ ТЕРИТОРИЙ НА ОСНОВЕ НЕЙРОННЫХ СЕТЕЙ}

Аннотация. Работа посвящена актуальной проблеме исследования влияния процессов миграции внутренне перемещенных лиц на отдельные социально-демографические показатели безопасности регионов. Особое значение эта проблема приобрела после начала вооруженного конфликта на территории Украины в 2014 г., который привел к стремительному росту процессов внутренней миграции. В частности, проанализирована динамика изменения следующих показателей: демографическая нагрузка, уровень безработицы, объем денежных переводов, близость расположения к линии разграничения.

В результате проведенного исследования автором было построено нейронную сеть типа карты Кохонена. Модель распределила обучающую выборку из регионов страны на шесть кластеров по уровню четырех показателей социально-демографической безопасности. Это позволило оценить влияние процессов вынужденной внутренней миграции на некоторые аспекты социально-экономической безопасности регионов. На основе полученной карты Кохонена показано, что Донецкая и Луганская области, которые непосредственно граничат с зоной ООС, имели катастрофический рост демографической нагрузки и уровня безработицы в течение исследуемого периода. Также в несколько раз сократились объемы денежных переводов мигрантов. Уровень социально-экономической безопасности регионов шестого кластера по выбранным показателям был определен как опасный. Полученные результаты могут быть использованы для формирования региональной социально-экономической политики и соответствующих национальной демографической 
и миграционной политик. Процесс кластерного анализа и предложенная система показателей позволяют осуществлять постоянный мониторинг и оценку влияния процессов вынужденной внутренней миграции на отдельные аспекты социально-экономической безопасности регионов.

Ключевые слова: социально-демографическая безопасность, демографическая нагрузка, уровень безработицы, линия разграничения, карта Кохонена, кластер.

\section{THE STUDY OF THE INFLUENCE OF FORCED MIGRATION PROCESSES ON PARTICULAR SOCIO-DEMOGRAPHIC INDICATORS OF TERRITORY SECURITY BASED ON NEURAL NETWORKS}

Annotation. The paper deals with the topical problem of studying the impact of migration processes of internally displaced persons on certain sociodemographic indicators of regional security. This problem became particularly important after the beginning of armed aggression on the territory of Ukraine in 2014, which led to a rapid increase in internal migration processes. In particular, the dynamics of change of the following indicators was analysed: demographic burden, unemployment rate, the volume of remittances and proximity to the line of demarcation.

As a result of the study, the author constructed a neural network of the Korhonen map type. The model divided the training sample from the regions of the country into six clusters according to the level of four indicators of socio-demographic security. This allowed us to assess the impact of forced internal migration on some aspects of socio-economic security of the regions. Based on the obtained Korhonen map, it is shown that the Donetsk and Luhansk Oblasts, which directly border the Joint Forces Operation (JFO) zone, had a catastrophic increase in the demographic burden and unemployment rate during the study period. The volume of remittances of migrants has also decreased several times. The level of socio-economic security of the regions of the sixth cluster was selected as dangerous according to the selected indicators. The obtained results can be used for the formation of regional socio-economic policy and the corresponding national demographic and migration policy. The cluster analysis process and the proposed system of indicators make it possible to constantly monitor and assess the impact of forced internal migration processes on certain aspects of socio-economic security of regions.

Keywords: socio-demographic security, demographic burden, unemployment rate, demarcation line, Korhonen map, cluster.

Постановка проблеми. Анексія Криму та розгортання збройної агресії на Сході у 2014 р. спричинили суттєві демографічні та соціальні зміни в житті регіонів: призвели до значних обсягів руйнувань об'єктів 
виробничої, транспортної та соціальної інфраструктур, посилили екологічні ризики. Особливо великі зміни відбулись в областях, що безпосередньо межують із зоною ООС (Луганській та Донецькій). Відбулись кардинальні зміни у стані економіки цих регіонів, на які до конфлікту припадало приблизно чверть обсягу промислового виробництва та велика частка експорту України. Ці процеси негативно вплинули на загальну та безпекову складову життєдіяльності мільйонів людей. Наслідком спаду виробництва та масового згортання малого і середнього бізнесу стало широкомасштабне скорочення робочих місць. В Україні розпочались процеси внутрішньої вимушеної міграції.

Отже, актуальною проте не достатньо вивченою залишається проблема дослідження впливу процесів вимушеної міграції на окремі соціально-демографічні показники безпеки територій.

Аналіз останніх досліджень та публікацій. Процеси вимушеної міграції внутрішньо переміщених осіб (ВПО) мають вплив майже на всі сфери життя суспільства, та найбільше - на демографічну, соціальну, економічну сфери, ринки праці та фінансів. Безумовно ці процеси впливають на рівень соціально-економічної безпеки країни та регіонів, зокрема на соціально-демографічну його складову. Але, не зважаючи на значну кількість досліджень у напряму вивчення соціальної або демографічної структур ВПО, проблематика кількісної оцінки впливу процесів вимушеної міграції на рівень соціально-економічної безпеки в регіональному розрізі залишається поза увагою науковців.

О. Хомра стверджував, що міграція - це природний вияв мобільності людини, мотивованої прагненням до поліпшення умов свого існування, повнішого і надійнішого задоволення своїх потреб [1]. Дослідженням проблем свободи пересування людини, відтворення населення, міграційних процесів, правового, політологічного, демографічного, соціального аспектів цих процесів та методів управління ними в різний час займалися такі вітчизняні вчені, як О. Гладуна, T. Гнатюк, Т. Драгунова, О. Іванкова-Стецюк, О. Піскун, І. Прибиткова, Ю. Римаренко, У. Садова, П. Шушпанова. Дослідженням людського розвитку, насамперед, соціально-демографічних його проблем займалася Е. Лібанова.

Серед зарубіжних вчених, які зробили значний вклад у дослідження теорії регіональних міграційних процесів, потрібно згадати: У. Бека, В. Зомбарта, Е. Лі, Н. Лумана, П. Педерсена, Дж. Равена, О. Старка, А. Шюца.

Кількісну оцінку масштабів міграційних потоків у світі здійснюють спеціалізовані організації, зокрема Департамент 3 економічних і соціальних питань Організації Об'єднаних Націй (Нью-Йорк, США) [2] та Інститут міграційної політики (Вашингтон, США) [3]. В Україні цими питаннями займається Державна служба статистики [4].

Формулювання мети статті. Метою цього дослідження є грунтовний аналіз впливу процесів вимушеної міграції на окремі соціально-демографічні показники безпеки 
територій та наступна формалізація отриманих результатів на основі інструментарію штучного інтелекту, зокрема нейронних мереж.

Виклад основного матеріалу. Проте недостатньо вивченими залишаються аспекти впливу процесів вимушеної внутрішньої міграції на рівень соціально-економічної безпеки регіонів. Насамперед це питання стосується областей, що мають спільні з ними кордони (підконтрольні Україні частина Донецької та Луганської областей, Харківська, Запорізька області), та м. Київ, де ВПО бачать більші перспективи щодо працевлаштування та рівня соціальної захищеності. На підтвердження даної тези наведемо структуру розподілу ВПО між регіонами України станом на 13 квітня 2020 р. (рис. 1).

Рівень економічної безпеки країни характеризується багатьма індикаторами. Тому на практиці застосовують інтегральні оцінки, які описували б зміну рівня економічної безпеки країни в динаміці у порівнянні з пороговими значеннями. Саме порівняння кількісно оціненого рівня економічної безпеки країни 3 пороговими значеннями є основним завданням аналізу економічної безпеки.

Порогове значення - це гранична величина, недодержання значень якої призводить до початку руйнівних дій та нерегульованих процесів у різних сферах життєдіяльності країни та іï територій, до формування дестабілізуючих тенденцій, або, навіть, переводить систему в кризовий стан.

Для визначення порогових значень індикаторів зазвичай, використовують методи [6-9]:

- функціональних залежностей (макро/мікроекономічні аналітичні або статистичні рівняння, методи Ахієзера-Гольца, теорії інформації);

- макроекономічних моделей, які адекватно відображають наслідки впливу дестабілізуючих факторів для конкретної країни в поточний період часу;

- експертних оцінок; врахування оцінок міжнародних організацій (порівняння основних макроекономічних показників з пороговими значеннями, що приймаються як значення не нижче середньосвітових);

- оцінки приростів економічного зростання країни за основними

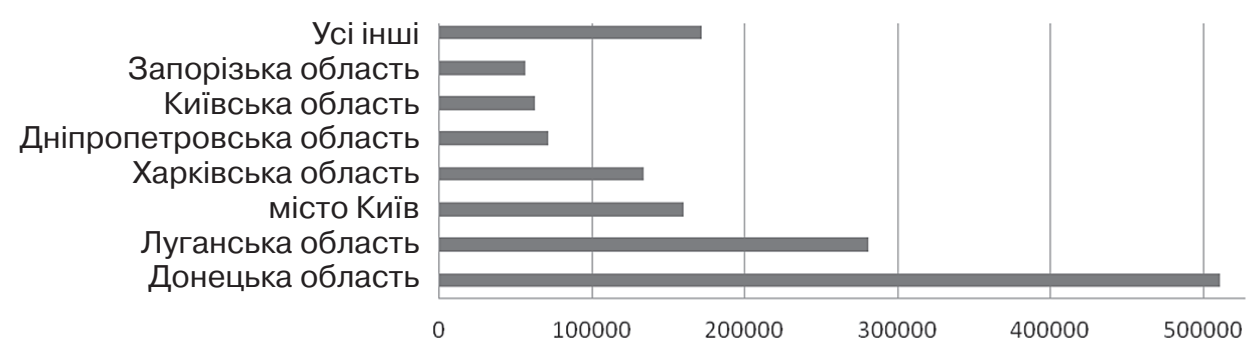

Рис. 1. Розподіл ВПО за областями України станом на 13 квітня 2020 р. Побудовано автором за даними УВКБ ООН в Україні [5] 
макроекономічними показниками та динамікою їх зміни;

- методи експертної оцінки та евристичні методи ("снігової кулі”; аналоговий підхід; калібрування; бальна оцінка рівня економічної безпеки та ранжування територій за ступенем загроз на основі аналізу фактичних індикаторів економічної безпеки);

- метод аналізу і обробки сценаpiïв;

• нелінійної динаміки (Вейвлетаналізу);

- стохастичні (діагностування: кластерний аналіз, нечітких множин; t-критерію; логістичної регресії, багатомірний статистичний аналіз);

- теоретико-ігрові методи;

- методи теорії корисності;

- методи розпізнавання образів;

- законодавчий підхід (встановлення порогових значень на законодавчому рівні).

Зазвичай використовують перші два методи, інші - лише у випадку неможливості їх застосування.

На сьогодні в Україні на законодавчому рівні закріплено методичні рекомендації до розрахунку рівня економічної безпеки країни, що по суті реалізовують індикативний підхід в оцінюванні вразливості національної економіки та в підсумку передбачають обчислення інтегральної оцінки [10]. Порівняно зі скасованою методикою від 2007 р. нова розробка має низку переваг, а саме [6]:

- визначення вектору граничних значень інтегральних показників;

- задання вагових коефіцієнтів для розрахунку внеску кожного субіндексу в інтегральний показник методом головних компонент;
- обгрунтування методу обертання факторних осей.

Дана методика має кілька відомих методологічних та технічних проблем при визначенні інтегрального показника економічної безпеки [6].

Класичний індикативний метод базується на комплексному аналізі індикаторів економічної безпеки та складається з наступних етапів:

- формування множини індикатоpiB;

- визначення характеристичних (оптимальних, порогових та граничних) значень індикаторів;

- нормалізація індикаторів;

- визначення вагових коефіцієнтів;

- розрахунок інтегрального індекcy.

Для адекватного опису динаміки та оцінки соціально-економічної безпеки регіону з огляду на військовий конфлікт, який триває на Сході країни, потрібно розширити відповідну систему базових показників. Визначимо множину індикаторів, що дають змогу кількісно оцінити вплив процесів вимушеної внутрішньої міграції на стан соціально-демографічної складової безпеки регіону. Автор пропонує використати такі специфічні критерії:

- темп зростання демографічного навантаження з початку ООС;

- темп зростання рівня безробіття з початку OOC;

- близькість розташування регіону до зони ООС;

- темп зростання обсягів грошових переказів з-за кордону з початку OOC.

Проаналізуємо окремо вплив вибраних показників на рівень соціаль- 
но-економічної безпеки регіону та їх динаміку під впливом процесів вимушеної внутрішньої міграції.

3 точки зору впливу на економіку регіону, зростання навантаження населенням похилого віку на працездатне населення призводить до зниження природного відновлення трудових ресурсів, що є проблемою для розвитку суспільного виробництва. Якщо частка пенсіонерів у загальній чисельності населення зростає, це спричиняє потребу у додатковому піклуванні про старших людей, призводить до збільшення економічної вартості з надання послуг щодо підтримки цієї категорії. Задля утримання й обслуговування населення похилого віку необхідно збільшувати непродуктивні витрати [11].

За даними УВКБ ООН в Україні [5] вікова структура ВПО за регіонами дуже відрізняється. Найвища кількість непрацездатного населення в структурі ВПО припадає на регіони, що безпосередньо граничать із зоною ООС та сусідні з ними регіони. Це істотно впливає на рівень де- мографічного навантаження на економічно-активне населення та рівень соціально-економічної безпеки цих регіонів.

Відповідно до визначення Державного комітету статистики демографічне навантаження (ДН) - це узагальнююча кількісна характеристика вікової структури населення, що показує навантаження на суспільство непродуктивним населенням. Демографічне навантаження подається у розрахунку на тисячу населення, тобто у проміле (\%о). Відповідно до цього ДН обчислюється за формулою:

ДН $=\frac{\text { Кількість осіб віком } 60 \text { років і старше }}{\text { Кількість населення віком 16-59 років }}$

На підтвердження припущення про суттєвий вплив процесів вимушеної внутрішньої міграції після 2014 р. на рівень соціально-економічної безпеки окремих регіонів побудуємо порівняльну таблицю показника загального ДН та порівняємо динаміку його зміни протягом періоду проведення ООС (таблиця).

Порівняння регіонів України за рівнем демографічного навантаження у період 3 01.01.14-01.01.19 pp.

\begin{tabular}{|l|c|c|l|}
\hline $\begin{array}{c}\text { Регіон, у порядку } \\
\text { зменшення ДН } \\
\text { (01.01.14) }\end{array}$ & дн (01.01.14) & Дн (01.01.19) & $\begin{array}{c}\text { Регіон, у порядку } \\
\text { зменшення Дн } \\
\text { (01.01.19) }\end{array}$ \\
\hline 1 & 2 & 3 & 4 \\
\hline Чернігівська & 421 & 489 & Луганська \\
\hline Черкаська & 393 & 480 & Донецька \\
\hline Кіровоградська & 385 & 459 & Чернігівська \\
\hline Донецька & 384 & 425 & Черкаська \\
\hline Вінницька & 378 & 421 & Сумська \\
\hline Полтавська & 376 & 416 & Кіровоградська \\
\hline Сумська & 375 & 415 & Запорізька \\
\hline Луганська & 370 & 403 & Полтавська \\
\hline
\end{tabular}


Закінчення табл.

\begin{tabular}{|l|l|l|l|}
\hline \multicolumn{1}{|c|}{1} & 2 & 3 & \multicolumn{1}{c|}{4} \\
\hline Хмельницька & 365 & 402 & Вінницка \\
\hline Запорізька & 364 & 399 & Хмельницька \\
\hline Житомирська & 355 & 396 & Дніпропетровська \\
\hline Дніпропетровська & 354 & 385 & Харківська \\
\hline Харківська & 346 & 384 & Миколаївська \\
\hline Миколаївька & 338 & 383 & Житомирська \\
\hline Київська & 337 & 380 & Херсонська \\
\hline Херсонська & 334 & 361 & Одеська \\
\hline Тернопільська & 331 & 357 & Київьька \\
\hline Одеська & 326 & 357 & Тернопільська \\
\hline Львівська & 306 & 344 & м. Київ \\
\hline Чернівецька & 302 & 343 & Львівська \\
\hline Івано-Франківська & 299 & 330 & Івано-Франківська \\
\hline м. Київ & 295 & 327 & Чернівецька \\
\hline Волинська & 285 & 314 & Волинська \\
\hline Рівненська & 273 & 303 & Рівненська \\
\hline Закарпатська & 258 & 286 & Закарпатська \\
\hline
\end{tabular}

Джерело: побудовано автором на основі даних [4].

За даними таблиці робимо висновок, що області, які територіально розташовані у безпосередній близькості до зони ООС протягом розглянутого періоду мали стрімку динаміку до зростання показника ДН. Зокрема, максимальний темп зростання спостерігається у Луганській (+32,2 \%) та Донецькій (+25 \%) областях, на які припадає більше 50 \% від усієї кількості ВПО. У порівнянні: середній темп приросту ДН в країні за цей період становив $11,7 \%$.

Зростання демографічного навантаження має несприятливі наслідки, що зокрема, призводять до розпиленості капіталовкладень у результаті перерозподілу їх з виробничих галузей у соціальну інфраструктуру, зни- ження рівня заощаджень у результаті збільшення споживання домашніх господарств.

Розглянемо наступний 3 вибраних показників: рівень безробіття (РБ) серед ВПО. Цілком закономірно, що значне зростання кількості ВПО призводить до пропорційного зростання рівня безробіття в регіоні. Аналіз даних щодо рівня безробіття за методологією Міжнародної організації праці (визначає рівень безробіття як відношення (у \%) кількості безробітних віком від 15 років і старше до робочої сили зазначеного віку або відповідної соціально-демографічної групи) за регіонами протягом періоду проведення ООС вказує на значне зростання РБ за регіонами, що межують із областю ООС. Зокре- 
ма, безпрецедентне зростання показника протягом розглянутого періоду маємо у Луганській (202 \%) та Донецькій областях (59,5 \%), при середньому рівні зростання РБ у $9,5 \%$, а в половині областей спостерігалось скорочення РБ.

Третім показником, що потрібно врахувати для оцінки впливу процесів вимушеної внутрішньої міграції на рівень соціально-економічної безпеки регіону, є близькість розташування (БР) до лінії розмежування, до зони ООС. Об'єктивність та необхідність врахування даного показника є безсумнівною. Проте кількісна оцінка територій за віддаленістю від лінії розмежування ускладнюється відсутністю в міжнародному праві чіткої методології щодо визначення зон збройної напруги в країнах із військовим конфліктом [12]. Тож у рамках цього дослідження автор пропонує експертну оцінку даного показника, що визначатиметься в балах. Шкала показника БР варіюється від 1 до 4 та поставлена відповідно до географічної віддаленості регіонів від лінії розмежування від максимального значення - для регіонів, що безпосередньо межують із зоною ООС (Донецька та Луганська області) до мінімального - регіони, що значно віддалені від цієї зони. Рівень БР рівний 3 мають області, що межують з регіонами із рівнем БР рівний 4 (Дніпропетровська, Запорізька, Харківська); БР рівний 2 для областей сусідніх із даними (Кіровоградська, Миколаївська, Полтавська, Сумська, Херсонська) та БР рівний 1 для усіх інших.

Останній показник, що пропонує врахувати автор у процесі кластерно- го аналізу динаміки окремих показників соціально-економічної безпеки регіонів під впливом вимушеної міграції ВПО є темп зростання обсягів грошових переказів 3-за кордону (ОГП). Це єдиний з вибраних показників, що відображає позитивний вплив процесів вимушеної міграції ВПО на безпеку регіонів.

Реалії сьогодення показують, що в умовах зниження інвестиційної привабливості, а також військово-політичного конфлікту, зростання обсягів грошових переказів та інвестиції ВПО, які змушені працювати за кордоном, можуть стати стабільним і довгостроковим ресурсом розвитку економіки регіонів [13].

Наявні дані Національного банку України дають можливість дослідити регіональний розподіл тільки частини грошових переказів в Україну, які надходять через міжнародні платіжні системи (Western Union, "Золотая корона", MoneyGram тощо). Тож дане дослідження обмежується саме офіційними статистичним даними та не робитиме припущень щодо обсягів грошових переказів іншими каналами надходжень. Такий підхід дасть змогу сформувати статистичну вибірку для побудови математичної моделі, що відповідає принципам порівнюваності.

На основі аналізу наявної статистичної інформації бачимо тенденцію до зростання показника ОГП у регіонах, на які припадає більшість чисельності ВПО. Важливе виключення становлять Донецька та Луганська області. У них спостерігається зниження надходжень ОГП, а отже, відсутність позитивного ефекту від процесів вимушеної внутріш- 
ньої міграції за даним показником. Це пояснюється найвищими рівнями ДН у регіонах, де більше половини ВПО складають пенсіонери. I, навпаки, більшість економічно активного населення з числа ВПО було зареєстровано у м. Київ, де протягом розглянутого періоду відбулося зростання ОГП на $309 \%$.

Зробимо узагальнення отриманих даних. На основі статистичної інформації щодо динаміки вибраних показників проведемо кластерний аналіз їх впливу на рівень соціально-економічної безпеки регіонів на основі нейронної мережі типу карти Кохонена. Карта Кохонена реалізує один з методів кластерного аналізу [14].

Дана нейронна мережа являє собою один шар нейронів, організований у вигляді двомірної матриці. Це дає можливість отримати візуальне зображення багатомірних вхідних даних. Карта Кохонена дає змогу здійснити кластеризацію об'єктів дослідження та проводити подальший аналіз ваг нейронів та розподіл прикладів за кластерами.

За результатами моделювання автором отримано карту Кохонена, що розділяє вибірку з 25 елементів (24 області та м. Київ) на кластери відповідно до рівня вибраних показників, що характеризують окремі аспекти впливу процесів вимушеної внутрішньої міграції на рівень соціально-економічної безпеки регіонів (рис. 2) [15].

Проаналізуємо отримані результати. Області України розподілились за кластерами відповідно до значень вибраних показників на 01.01.2014 року наступним чином:

- кластер 1: Закарпатська, Запорізька, Івано-Франківська, Київська, Миколаївська, Сумська, Тернопільська;
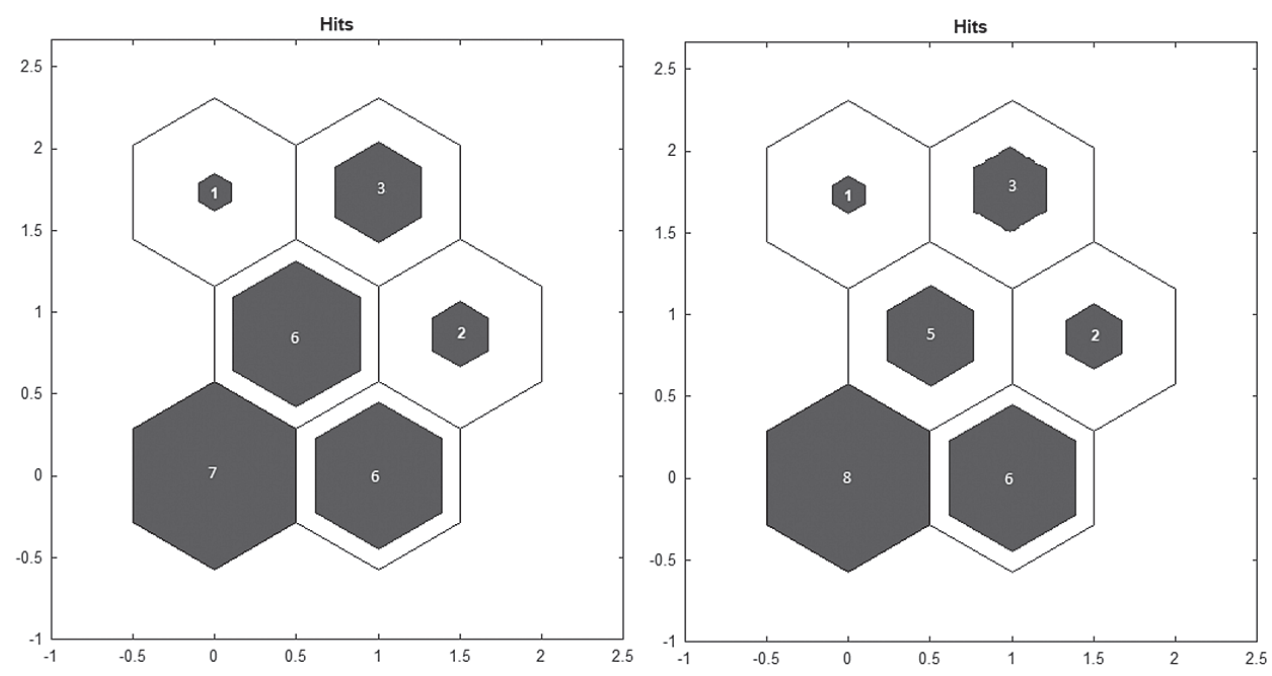

Рис. 2. Зліва на право: карта Кохонена, отримана у результаті моделювання розподілу регіонів України за окремими показниками соціально-економічної безпеки за даними на 01.01.2014 р.; за даними на 01.01.2019 р. Джерело: побудовано автором. 
- кластер 2: Волинська, Рівненська, Херсонська, Хмельницька, Черкаська, Чернівецька;

- кластер 3: Дніпропетровська, Донецька, Львівська, Луганська, Одеська, Харківська;

- кластер 4: Кіровоградська, Чернігівська;

- кластер 5: м. Київ;

- кластер 6: Вінницька, Житомирська, Полтавська.

Розглянемо отримані кластери відповідно до вибраних показників соціально-економічної безпеки та порівняємо зміну в кластерній структурі навчальної вибірки під впливом процесів вимушеної внутрішньої міграції (рис. 2).

Найвищий рівень безпеки за вибраними показниками на 01.01.2014 р. спостерігався у м. Київ (кластер 1), Дніпропетровській, Донецькій, Львівській, Луганській, Одеській та Харківській областях (кластер 3). Їм були притаманні поєднання найнижчих та середніх значень показників демографічного навантаження, рівня безробіття та обсягів грошових переказів. Такий результат є цілком обгрунтованим ядро кластеру 3 складають історично сформовані індустріальні регіони України, а м. Київ - фінансовоадміністративний центр країни 3 усіма відповідними перевагами та можливостями.

Стабільним рівнем безпеки характеризується кластер 1 - він є найбільшим за розміром і включає області з невисоким рівнем безробіття, демографічного навантаження на економічно активне населення та високими значеннями показника ОГП, що значно перевищують відповідні потоки іноземних інвестицій у регіони.

Трохи гірші значення досліджуваних показників відповідають кластеру 2. Рівень безпеки областей, що увійшли до нього, за вибраними показниками автором визначається як нижчий за середній.

Найгірше становище НД, РБ та ОГП були характерні на 01.01.2014 p. для Вінницької, Житомирської, Полтавської (кластер 6), Кіровоградської та Чернігівської областей (кластер 4). Останні дві мають найгірші значення показників, а отже, і рівень соціально-економічної безпеки визначений автором як "небезпечний". Рівень соціально-економічної безпеки регіонів кластеру 6 був загрозливим.

Під впливом процесів вимушеної внутрішньої міграції в кластерній структурі навчальної вибірки відбулися зміни. Тож області України розподілились за кластерами відповідно до значень вибраних показників на 01.01.2019 р. таким чином:

- кластер 1: Вінницька, Житомирська, Закарпатська, Рівненська, Тернопільська, Хмельницька, Черкаська, Чернівецька;

- кластер 2: Івано-Франківська, Київська, Львівська, Миколаївська, Одеська, Херсонська;

- кластер 3: Волинська, Кіровоградська, Полтавська, Сумська, Чернігівська;

- кластер 4: Донецька, Луганська;

- кластер 5: м. Київ;

- кластер 6: Запорізька, Дніпропетровська, Харківська.

Небезпечний рівень соціальноекономічної безпеки за вибраною сукупністю показників мають До- 
нецька та Луганська області - кластер 4. 3 початку військової агресії на сході, що спричинив значний потік ВПО до цих регіонів, їх статус 3 “найвищого рівня безпеки” змінився на "небезпечний". Висока частка в структурі ВПО населення непрацездатного віку спричинило катастрофічне зростання показників демографічного навантаження та рівня безробіття в областях. Натомість не відбулось зростання обсягів грошових переказів, позитивна динаміка яких також напряму залежить від кількості економічно активного населення в регіоні. Крім того, області безпосередньо граничать із зоною ООС, що відповідно до запропонованого алгоритму надає територіям найвищі значення показника БР та відображає додаткові ризики, пов'язані з цим.

Відповідно до отриманого розподілу загрозливим залишається рівень безпеки у Волинській, Кіровоградській, Полтавській, Сумській та Чернігівській областях.

Під впливом процесів вимушеної внутрішньої міграції показники демографічного навантаження, рівня безробіття значно зросли у Запорізькій, Дніпропетровській та Харківській областях. Крім того, РБ рівний 3 для цих областей. Через це навчена нейронна мережа віднесла їх до одного кластера. Проте рівень соціально-економічної безпеки цих регіонів залишається вищим за середній, зокрема через зростання потоків грошових переказів та невисокого рівня безробіття. Отримані результати дозволяють зробити висновок, що незважаючи на близькість розташування до лінії розмежування, значна кількість ВПО не привела до катастрофічного зниження рівня соціально-економічної безпеки. Однією 3 причин є відмінність у демографічній структурі ВПО. Порівняно з Донецькою та Луганською областями регіони 6 кластеру співвідношення між особами працездатного та пенсійного віку становить 80-90 \% (89 осіб працездатного віку на 10 пенсіонерів), у той час як у 4 кластері аналогічний показник дорівнює $24 \%$ (Донецька область) та 17 \% (Луганська область).

Найвищий рівень безпеки має кластер 5. Він складається з одного елемента навчальної вибірки м. Києва. Хоч статус найбільш безпечного регіону за вибраною системою показників формально не змінився, на прикладі м. Київ можна спостерігати позитивний ефект від потоку ВПО з 2014 р. Причиною цього знову є демографічна структура: наведене раніше співвідношення між особами працездатного віку та пенсіонерами у ВПО становить $231 \%$. Це означає, що на одного пенсіонера приходиться дві особи працездатного віку. Як наслідок, більше ніж у три рази зросли обсяги грошових потоків від мігрантів, невисокий рівень безробіття та демографічного навантаження.

Кластери 1 і 2 характеризуються середнім та високим рівнем соціально-економічної безпеки за вибраними показниками.

На основі узагальнених характеристик у вигляді середніх значень ознак всередині кожного 3 шести кластерів автором було побудовано діаграму розсіювання у системі координат "рівень безробіття-демо- 
графічне навантаження", що наочно демонструє складову соціально-демографічної безпеки кожної групи. Розмір елемента на діаграмі відповідає середньому обсягу грошових переказів у кластері. Стрілкою вказано вектор погіршення рівня соціально-демографічної складової безпеки регіонів, що складають відповідний кластер (рис. 3).

Отримані усереднені значення показників рівня безробіття, демографічного навантаження, обсяг грошових переказів мігрантів та близькість розташування до лінії розмежування підтверджують отримані автором висновки щодо впливу процесів вимушеної внутрішньої міграції на окремі аспекти рівня соціально-демографічної безпеки регіонів.

Ситуація на сході країни вимагає додаткових досліджень концептуального підходу до оцінки рівня економічної безпеки регіонів. У світлі цих подій стає зрозумілим, що адекватне управління безпекою економіки регіонів неможливе без врахування ризиків значних коливань в окремих її показниках під впливом процесів вимушеної внутрішньої міграції.

Висновки і перспективи подальших досліджень. У результаті проведеного дослідження автором було побудовано нейронну мережу типу карти Кохонена. Модель розподілила навчальну вибірку з 25 регіонів (24 області та м. Київ) на шість кластерів за рівнем чотирьох показників соціально-демогрфічної безпеки. Це дало змогу оцінити вплив процесів вимушеної внутрішньої міграції на деякі аспекти соціально-економічної безпеки регіонів. Зокрема, на основі отриманої карти Кохонена показано, що Донецька та Луганська області, які безпосередньо межують із зоною OОС, мали катастрофічне зростан-

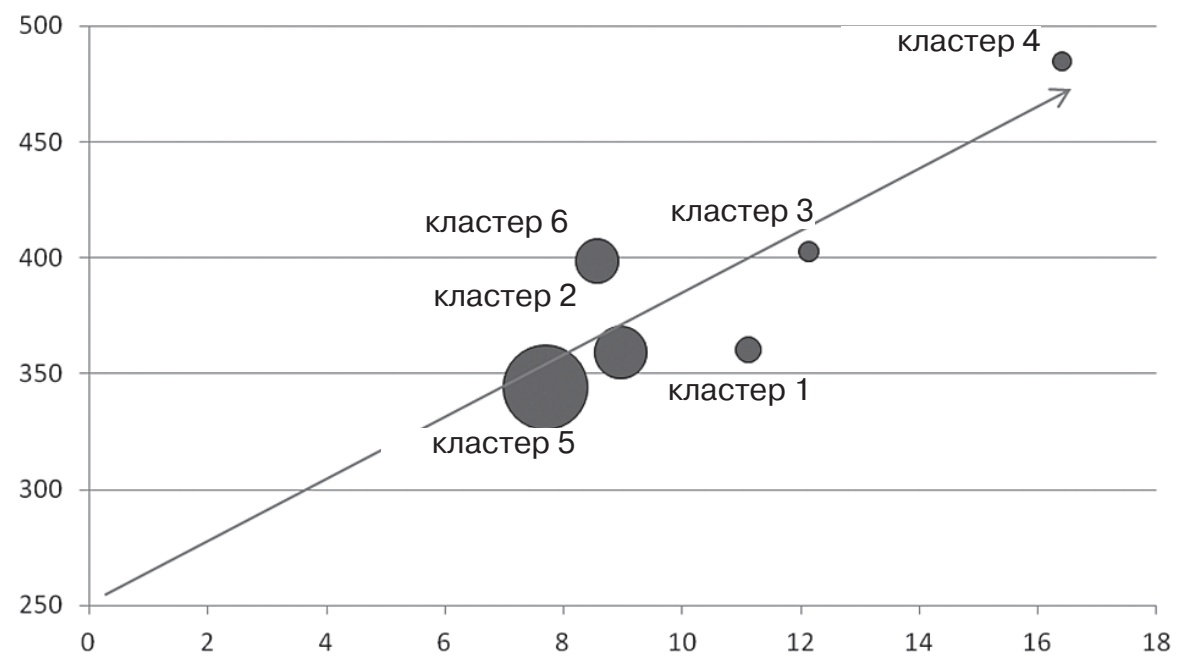

Рис. 3. Діаграма розсіювання узагальнених характеристик окремих показників соціально-економічної безпеки регіонів по кластерах карти Кохонена за даними 2019 р.

Джерело: побудовано автором. 
ня демографічного навантаження та рівня безробіття протягом досліджуваного періоду. Також у кілька разів скоротились обсяги грошових переказів мігрантів. Рівень соціальноекономічної безпеки регіонів кластеру 6 за вибраними показниками був визначений як небезпечний. На противагу у м. Київ, що має значні обсяги прибуття ВПО, зафіксовано зростання рівня соціально-економічної безпеки за вибраними показниками. Це пов'язано з демографічною структурою ВПО регіону. Співвідношення між особами працездатного віку та пенсіонерами у ВПО становить 231 \%. Як наслідок, більше ніж у три рази зросли обсяги грошових потоків від мігрантів, невисокий рівень безробіття та демографічного навантаження.

Стабільно високим протягом розглянутого періоду залишається рівень безпеки областей, що межують 3 Донецькою та Луганською. У них не зафіксовано катастрофічного впливу процесів вимушеної внутрішньої міграції, проте існувало зростання показника демографічного навантаження.

Отримані результати можуть бути використані для формування регіональної соціально-економічної політики і відповідної національної демографічної та міграційної політики.

Процес кластерного аналізу та запропонована система показників дають можливіть здійснювати постійний моніторинг та оцінку впливу процесів вимушеної внутрішньої міграції на окремі аспекти соціально-економічної безпеки регіонів.

\section{СПИСОК ВИКОРИСТАНИХ ДЖЕРЕЛ}

1. Хомра О. У. Мігранти України в соціально-економічному вимірі / О. У. Хомра // Стратегічна панорама. 2005. № 3. С. 171-179.

2. United Nations Department of Economic and Social Affairs [Електронний ресурс]. Режим доступу: http://www.un.org/en/development/ desa/index.html

3. Migration policy institute [Електронний ресурс]. Режим доступу: http://www. migrationinformation. org/programs/data-hub/mapsimmigrants-and-emigrantsaroundworld

4. Державна служба статистики України. Офіційний веб-сайт. [Електронний ресурс]. Режим доступу: http:/ www.ukrstat.gov.ua

5. Агентство ООН у справах біженців. Офіційний веб-сайт [Електронний peсурс]. Режим доступу: https:// www.unhcr.org/ua/resources

6. Харазішвілі Ю. М. Щодо вдосконалення методології інтегрального оцінювання рівня економічної безпеки України: Аналітична записка / Ю. М. Харазішвілі, А. І. Сухоруков, Т. П. Крупельницька. НІСД, вересень 2013 р. [Електронний ресурс]. Режим доступу: http://www.niss. gov.ua/articles/1358/

7. Интрилигатор М. Математические методы оптимизации и экономическая теория: пер. с англ. / под ред. А. А. Конюса. М. : Прогресс, 1975. 599 c.

8. Strelchenko I. I. Modelling an effective sales strategy of enterprise, that selling products at the domestic market and abroad / I. I. Strelchenko // Actual Economic Problem. 2015. № 6.

9. Основы экономической безопасности (Государство, регион, предприятие, личность) / под ред. 
Е. А. Олейникова. М.: ЗАО “Бизнес-школа "Интел-Синтез”, 1997. $288 \mathrm{c}$.

10. Про затвердження Методичних рекомендацій щодо розрахунку рівня економічної безпеки України від 29.10.2013 р. № 1277 [Електронний ресурс]. Режим доступу: http://search.ligazakon.ua/1_doc2. nsf/link1/ME131588.html

11. Статівка Н. В. Демографічна складова економічної безпеки України / Н. В. Статівка, А. А. Смаглюк // Теорія та практика державного управління. 2011. Вип. 1. С. 280-287.

12. Bartels $R$. Timelines, borderlines and conflicts. The historical evolution of the legal divide between international and non international armed conflicts / International Review of the Red Cross, Volume 91, n873, March 2009, p. 35-67.

13. Гайдуиький A. 3 третього світу в перший - завдяки грошовим переказам мігрантів / А. Гайдуцький // Зеркало недели. 2015. Вип. 19 [Електронний ресурс]. Режим доступу: https://dt.ua/finances/z-tretogosvitu-v-pershiy-zavdyaki-groshovimperekazam-migrantiv-_html

14. Kohonen T. Self-Organizing Maps (Third Extended Edition), New York, 2001, 501 p.

15. Arakelova I. (2020). The influence of the internally displaced persons forced migration on the dynamics of regional social and economic security indicators // Economic Annals-XXI, 182(3-4), 4-14. [in English].

\section{REFERENCES}

1. Khomra O. U. (2005) Migranty Ukrayiny v socialno-ekonomichnomu vymiri [Migrants of Ukraine in the socio-economic dimension]. Strategichna panorama - Strategic panorama, 3, 171-179 [in Ukrainian].
2. United Nations Department of Economic and Social Affairs Retrieved. wroro.un.org. from: //www.un.org/en/ development/desa/index.html. [in English].

3. Migration policy institute. http:// wrore. migrationinformation.org. Retrieved from: //www. migrationinformation.org/programs/data-hub/ maps-immigrants-and-emigrantsaround-world. [in English].

4. Sajt Derzhavnoyi sluzhby statystyky Ukrayiny. http://wow.ukrstat.gov.ua. Retrieved from: //www.ukrstat.gov. ua. [in Ukrainian].

5. Sajt agentstvo OON u spravax bizhenciv v Ukrayini. https://wrow.unhcr.org. Retrieved from: //www.unhcr.org/ ua/resources. [in Ukrainian].

6. Yu. M. Xarazishvili, A. I. Suxorukov \& T. P. Krupelnyczka. (2013). Shhodo vdoskonalennya metodologiyi integralnogo ocinyuvannya rivnya ekonomichnoyi bezpeky' Ukrayiny: Analitychna zapyska [Regarding the improvement of the methodology of integrated assessment of the level of economic security of Ukraine: Analytical note]. http://wror.niss.gov.ua. Retrieved from: //www.niss.gov.ua/ articles/1358/. [in Ukrainian].

7. Intrylygator M. (1975). Matematycheskye metody optymyzacyy y ekonomycheskaya teoryy. [Optimization Mathematical Methods and Economic Theory]. Moscow: Progress. [in Russia].

8. Strelchenko I. I. (2015). Modelling an effective sales strategy of enterprise, that selling products at the domestic market and abroad. Actual Economic Problem. 6, 469-475. [in English].

9. Olejnykov E. A. (Eds.) (1997). Osnovy ekonomycheskoj bezopasnosty (Gosudarstoo, regyon, predpryyatye, lychnost). [Fundamentals of economic security (State, region, enterprise, per- 
sonality)]. Moscow: By'znes-shkola "Intel-Syntez". [in Russia].

10. Pro zatverdzhennya Metodychnyh rekomendacij shhodo rozraxunku rivnya ekonomichnoyi bezpeky Ukrayiny. № 1277 vid 29.10.2013. [About the consolidated Methodical Recommendations for the development of the level of economic security of Ukraine. № 1277 of 29.10.2013] p. n.d. http:// ligazakon.ua. Retrieved from: // search.ligazakon.ua/1_doc2.nsf/link1/ ME131588.html. [in Ukrainian].

11. Stativka N. V. \& A. A. Smaglyuk. (2011). Demografichna skladova ekonomichnoyi bezpeky Ukrayiny. [Demographic component of economic security of Ukraine]. Teoriya ta praktyka derzhavnogo upravlinnya. [Theory and practice of public administration]. 1, 280-287. [in Ukrainian].

12. Bartels R. (2009). Timelines, borderlines and conflicts. The historical evolution of the legal divide between international and non international armed conflicts. International Review of the Red Cross. 873, 35-67 [in English].

13. Gajduczkyj A. (2015). Z tretogo svitu v pershyj - zavdyaky groshovym perekazam migrantiv. [From the third world to the first - due to remittances of migrants]. n.d. http://dt.ua/ finances. Retrieved from: //dt.ua/ finances/z-tretogo-svitu-v-pershiyzavdyaki-groshovim-perekazam-migrantiv-_html. [in Ukrainian].

14. Kohonen T. (2001). Self-Organizing Maps. New York. [in English]. 